\title{
Olfactory Basal Cell
}

National Cancer Institute

\section{Source}

National Cancer Institute. Olfactory Basal Cell. NCI Thesaurus. Code C13153.

A cell found in the pseudostratified epithelium lining the olfactory region of the nasal cavity. It gives rise to olfactory receptor cells and sustentacular cells. 